\title{
熱拡散白金ルテニウム合金触媒の組成比が耐一酸化炭素被毒特性へ与える影響
}

\author{
多田 智之 ${ }^{\mathrm{a}, \mathrm{b}} *$, 山本 夕美 $\mathrm{a}$, 光島 重徳 ${ }^{\mathrm{b}}$, 太田健一郎 ${ }^{\mathrm{b}}$ \\ ${ }^{a}$ 田中貴金属工業株式会社（干 254-0076 平塚市新町 2-73） \\ b 横浜国立大学大学院（† 240-8501 横浜市保土ヶ谷区常盤台79-5）
}

\section{The Effect of Pt : Ru Ratio of Thermal Alloying PtRu Catalyst on CO-tolerance}

\author{
Tomoyuki Tada, ${ }^{\mathrm{a}, \mathrm{b}} *$ Yumi Yamamoto, ${ }^{\text {a }}$ Shigenori Mitsushima, ${ }^{\mathrm{b}}$ and Kenichiro OTa ${ }^{\mathrm{b}}$ \\ aTanaka Kikinzoku Kogyo K. K. (2-73 Shinmachi, Hiratsuka, Kanagawa 254-0076, Japan) \\ ${ }^{\text {b} Y o k o h a m a ~ N a t i o n a l ~ U n i v e r s i t y ~(79-5 ~ T o k i w a d a i, ~ H o d o g a y a-k u, ~ Y o k o h a m a, ~ K a n a g a w a ~ 240-8501, ~ J a p a n) ~}$
}

Received July 31, 2008 ; Accepted September 10, 2008

\begin{abstract}
Platinum-ruthenium catalysts of various Pt:Ru ratios were prepared by a newly developed three-step method for use as anodes in stationary polymer electrolyte fuel cells. As the first step, a well-dispersed platinum catalyst was prepared, and then ruthenium was deposited in the vicinity of the platinum particles by a chemical deposition method as the second step. As the final step, the Pt-Ru catalysts were heat-treated to obtain well-alloyed structures. The Pt-Ru catalysts prepared by this method showed good CO tolerance, even though the particle size was relatively large. The $\mathrm{CO}$ tolerance increased with increasing the ruthenium content, and the highest $\mathrm{CO}$ tolerance was obtained at Pt : Ru ratios in the range of $1: 2$ to $1: 3$. On air bleeding, the catalysts of a wider range of Pt : Ru ratios showed good CO tolerance. Potential sweep durability tests revealed that the stability of the Pt-Ru catalysts of $\mathrm{Pt}: \mathrm{Ru}=1: 1$ against high potentials (1000 mV vs. RHE) was lower than that of the catalysts of $\mathrm{Pt}: \mathrm{Ru}=1: 1.5$ and $1: 2$.
\end{abstract}

Key Words : Fuel Cell, Platinum-ruthenium Catalyst, CO-tolerance, Ratio of Platinum and Ruthenium

\section{1 緒 言}

固体高分子形燃料電池は，来るべく水素社会に扔いて重要 な役割を担うであろう発電システムであり，自動車用の動力 源への適用を目指して，また，各家庭での発電と給湯を担う コージェネレーションシステムとしての適用を目指して，盛 んに開発が進められている. 特に後者の家庭用のコージェネ レーション燃料電池システムの開発は, 日本の技術開発が世 界を牽引しており，既に実際の家庭をフィールドにした大規 模な実証試験が実施されている。近年の国を挙げての燃料電 池開発の取り組みは，各社の燃料電池システムの性能向上を 実現しただけでなく，基礎的アプローチによって燃料電池材 料などの劣化機構の解明に貢献し, 結果として燃料電池シス テムの耐久性が改善されるなど，確実に成果を挙げつつある。 家庭用燃料電池は，都市ガスなどの燃料をべースにシステム 内で燃料を改質して水素を生成させるため，それに起因した このシステム特有の触媒的課題が存在する. その一つが改質 システムに用いられる触媒の性能および耐久性の改善で, 改 質触媒，シフト触媒，選択酸化触媒と，それぞれの触媒につ いて精力的に技術開発が実施されている。 その成果として, 水素中に含まれる一酸化炭素濃度は定常べースでは安定して $10 \mathrm{ppm}$ を切る程になった。一方，スタックに用いられる電 極触媒では，この微量な一酸化炭素濃度といえども触媒性能
を低下させるには十分な一酸化炭素濃度であるため, 耐一酸 化炭素被毒特性の向上を図るべく検討が実施されてきた。こ の一酸化炭素被毒に対して強い耐性を持つ触媒としては, 1960 年代から白金ルテニウム触媒の存在が知られ，白金ル テニウム触媒の耐一酸化炭素被毒特性の発現機構などの調査, 触媒構造の最適化などが実施されてきた ${ }^{1-5)}$.

水素に一酸化炭素が混入した燃料を用いて発電を実施した 場合には, 燃料極の触媒表面上で水素の吸着と一酸化炭素の 吸着の競争反応が起こっていると考えられている.

$$
\begin{aligned}
& \mathrm{Pt}+\mathrm{CO} \rightarrow \mathrm{Pt}-\mathrm{CO}_{\text {ads }} \\
& 2 \mathrm{Pt}+\mathrm{H}_{2} \rightarrow 2 \mathrm{Pt}-\mathrm{H}_{\mathrm{ads}}
\end{aligned}
$$

固体高分子形燃料電池のような低温の燃料電池においては, 一酸化炭素の触媒表面上への吸着が強固なために, 水素の吸 着および酸化に必要な触媒表面の有効サイトが一酸化炭素に よって被覆され, 水素の吸着掞よび酸化が阻害され性能低下 が生じる。したがって，この一酸化炭素の被覆を低減するこ と，すなわち，一酸化炭素の被覆がどのようなメカニズムによ って低減されるかを解明することが, 耐一酸化炭素被毒触媒 を開発するうえで鍵となる．白金表面に吸着した一酸化炭素 を除去する反応としては以下の反応メカニズムが想定される. 


$$
\begin{gathered}
\mathrm{Pt}+\mathrm{H}_{2} \mathrm{O} \rightarrow \mathrm{Pt}-\mathrm{OH}_{\mathrm{ads}}+\mathrm{H}^{+}+\mathrm{e}^{-} \\
\mathrm{Pt}-\mathrm{CO}_{\mathrm{ads}}+\mathrm{Pt}-\mathrm{OH}_{\mathrm{ads}} \rightarrow 2 \mathrm{Pt}+\mathrm{CO}_{2}+\mathrm{H}^{+}+\mathrm{e}^{-}
\end{gathered}
$$

ところで，白金は500 mV（vs. RHE）以下では水を吸着し ないことが知られ，したがって，(4) の白金表面に吸着した 一酸化炭素の酸化による脱離反応は500 mV（vs. RHE）以 下では生じ得ない。そのため，白金では吸着した一酸化炭素 の除去が通常の燃料電池の反応環境下である $100 \mathrm{mV}$ (vs. RHE）以下のアノード電位では起こらず，顕著な一酸化炭 素被毒現象が観察される 6,7$)$. 白金表面に吸着した一酸化炭 素を除去する方策として，白金と別の金属との合金化や酸化 物との複合化などの手法が盛んに検討されている ${ }^{8-11)}$. 合金 化や酸化物との複合化効果による耐一酸化炭素被毒発現のメ カニズムは，その金属種や酸化物種によって異なることが予 想される．特に最も高い効果を発揮する白金ルテニウム触媒 の系では既に多くの議論が成されている $4,11-20)$.

Watanabeらは，白金ルテニウム触媒が高い耐一酸化炭素 被毒特性を示すのは，白金表面へ吸着した一酸化炭素がルテ ニウム表面に吸着した酸素含有成分によって酸化される “Bi-functional mechanism”によると提案した4).

$$
\begin{gathered}
\mathrm{Pt}+\mathrm{CO} \rightarrow \mathrm{Pt}-\mathrm{CO}_{\mathrm{ads}} \\
\mathrm{Ru}+\mathrm{H}_{2} \mathrm{O} \rightarrow \mathrm{Ru}-\mathrm{OH}_{\mathrm{ads}}+\mathrm{H}^{+}+\mathrm{e}^{-} \\
\mathrm{Pt}-\mathrm{CO}_{\mathrm{ads}}+\mathrm{Ru}-\mathrm{OH}_{\mathrm{ads}} \rightarrow \mathrm{Pt}+\mathrm{Ru}+\mathrm{CO}_{2}+\mathrm{H}^{+}+\mathrm{e}^{-}
\end{gathered}
$$

この反応機構は，白金ルテニウム表面へ吸着した一酸化炭素 の脱離が白金表面と比べて 200〜300 mV（vs. RHE）も低い 電位にて生じることによって類推され，白金やルテニウム上 への一酸化炭素と $\mathrm{OH}$ などの酸素含有成分の吸着の挙動を詳 細に検討することによって検証された。この反応メカニズム は, Gasteiger らによるルテニウムを白金上へ被覆したモデ ル触媒を用いた系における硫酸溶液中の一酸化炭素の酸化挙 動の調査 ${ }^{12,13)}$ ，Friedrich らによるFT-IRを用いた一酸化炭素 の吸着脱離挙動の解析 ${ }^{15}$, Iwase らによる燃料電池反応中の 出口ガスでの二酸化炭素の確認 ${ }^{21)}$ などによって支持され, 現在も白金ルテニウムが耐一酸化炭素被毒特性を示す主の理 由と考えられている。

一方，電解液中での一酸化炭素の脱離は白金ルテニウム触 媒でも $300 \mathrm{mV}$ (vs. RHE) 以下では起こらず，かつ，実際 の燃料電池反応の燃料極が $100 \mathrm{mV}$ (vs. RHE) 以下にて耐 一酸化炭素被毒特性を発揮することを考慮すると，この “Bi-functional mechanism”で耐一酸化炭素被毒特性の発現 メカニズムは説明できないとの主張も存在する. Cooperら は, 燃料極電位が $200 \mathrm{mV}$ (vs. RHE) 以下の燃料電池反応 の出口ガスに二酸化炭素をほとんど検出できなかったことか ら, 燃料電池定常発電時の一酸化炭素被毒特性発現効果は白 金ルテニウムの持つ本来の特性が変化した “Intrinsic effect” によって発現しているとした ${ }^{11)}$. 白金へのルテニウムの添加 によって, 触媒の電子状態が変化し, 結果として一酸化炭素 との結合状態に変化を与えたことが主要因だと結論付けてい る。この主張は, RusselらのX線吸収スペクトルによる白 金-白金の結合距離がルテニウムの添加によって影響を受け たとの解析 ${ }^{20)}$, また, Giorgi らの硫酸中でのインピーダンス 測定による，白金と白金ルテニウム合金上で水素酸化のメカ ニズムが異なっているとの解析によっても支持されている ${ }^{19)}$.
耐一酸化炭素被毒特性発現のメカニズムについて，これ以上 の言及は避けるが，ルテニウムの添加によって耐一酸化炭素 被毒特性が発現することは周知の事実である.

白金表面に吸着した一酸化炭素を除去する別の手法として， 水素中に微量の酸素を添加して吸着した一酸化炭素を直接燃 焼させる手法（エアーブリーディング法）がGottesfeld らに よって提案されている ${ }^{22,23)}$.

$$
\mathrm{Pt}-\mathrm{CO}_{\mathrm{ads}}+1 / 2 \mathrm{O}_{2} \rightarrow \mathrm{Pt}+\mathrm{CO}_{2}
$$

実際の燃料電池䨌囲気でも，エアーブリーディング法によっ て触媒表面に吸着した一酸化炭素の除去を促すことが多くの 実験によって確認され, 一酸化炭素被毒対策として現実的に 最も有効な手法と考えられている.

既に多くの研究者が最適な白金ルテニウムの組成 $2,5,6,18,19,21,24)$ や，白金ルテニウム触媒の製法 ${ }^{21,25-29)}$ に関して詳細な報告を 実施している。また，実用を意識しての白金ルテニウム触媒 の製法に関する特許も多く公開されている ${ }^{30-32) .}$

白金表面をルテニウムで被覆したモデル触媒などを用いた 系では，ルテニウムの被覆率が $50 \%$ 前後のときに最も効率 よく一酸化炭素の除去が進むと多くの研究者が述べてい る ${ }^{4,12,13,15)}$. 一方, Gasteiger らは同様のモデル触媒を用いた 水素 /一酸化炭素系で，ルテニウムの被覆率が90\%の時に 最も効率良く水素の酸化反応が進むと報告した ${ }^{14)}$ 。この結果 は，ルテニウムの被覆率が $90 \%$ の時には，白金表面を被覆 した一酸化炭素の除去がわずかながら低電位において生じた ことに起因しているとしている. Lin らは，ルテニウムの被 覆率が $75 \%$ の時に最も低い電位で一酸化炭素の除去ができ ると報告した ${ }^{18)}$ 。詳細な RHEEDの解析によって，ルテニウ ムの被覆率が高いときにはルテニウムのアイランドが生じて いることを確認し, それが一酸化炭素酸化の起点となるから と考察した. 実際の担持触媒を用いた系においても, 多くの 研究者が白金とルテニウムのモル比が $1 ： 1$ の時に耐一酸化 炭素被毒特性が最大になるとしている $2,6,7,19,21)$. 一方，りん酸 形燃料電池の系ではあるが, Ross らは白金とルテニウムの モル比が $3 ： 97$ の時に耐一酸化炭素被毒特性が最大になる と報告した ${ }^{5)}$. また，固体高分子形燃料電池の系においては, Zawodzinski らが耐一酸化炭素被毒特性と発電温度の関係を 調査し, $80^{\circ} \mathrm{C}$ では白金とルテニウムのモル比が $1 ： 1$ の時に

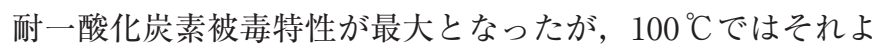
りも白金含有率の高い時に優れた耐一酸化炭素被毒特性を示 したと報告している ${ }^{24)}$.

ところで，これら担持触媒を用いた系での報告は，ほとん どの場合において担持触媒の調製を，白金とルテニウムを共 析する手法で作製している。共析した触媒でも，X線回折な どによって白金とルテニウムが十分に合金化されていること が報告されている例もあるが，表面の酸化状態などは触媒の 作製手法などによって様々な状態を取っていることが推測さ れる，幾つかの報告においては，白金とルテニウムを共析さ せた後，加熱処理を施した例もあるが，その目的は白金とル テニウムをより合金化するための目的でなく，微粒子を作製 するために用いたコロイド保護剤を取り除くといったことが 主眼に置かれているため，粒子成長がなるべく生じない条件 において実施されている。

著書らは，長年にわたり白金ルテニウム触媒の調製法を検 
討した結果，高い耐一酸化被毒特性を発現する触媒は，高分 散白金触媒を作製した後にルテニウムを白金近傍に担持し， その後高温での加熱処理を施すことによって作製できること を見出した ${ }^{32,33)}$ 。この手法で得られる触媒は従来の触媒調整 法で得られる触媒とミクロレベルでの触媒構造や表面状態が 大きく異なるので，耐一酸化炭素被毒特性等に対する従来の 実験事実が当てはまらない可能性がある。たとえば，高い耐 一酸化炭素被毒特性を得るための白金とルテニウムの最適組 成が異なることが予測される。

本研究では，この手法を用いて白金とルテニウムの組成比 の異なる白金ルテニウム触媒を作製し，それら触媒を用いて 触媒の物性調査，および，様々な条件下における耐一酸化炭 素被毒特性を調查し, 従来の知見との相違点を議論すること を目的とした。

\section{2 実 験}

\section{1 白金ルテニウム触媒の作製}

触媒作製のフロー図を Fig. 1 に示す。白金 $38.5 \mathrm{wt} \%$ 触媒 (TEC10E40E，田中貴金属工業製） $5.0 \mathrm{~g}$ に $8.4 \%$ 塩化ルテニ ウム溶液（田中貴金属工業製）を加えて, 白金：ルテニウム のモル比が $9 ： 1 \sim 1 ： 3$ とした. その後, 蒸留水を加え約 $450 \mathrm{ml}$ とし, 更にメタノールを $50 \mathrm{ml}$ 加え 8 時間還流してル テニウムを白金表面へ析出させた。 その後，乃過洗浄して得 た触媒を $60{ }^{\circ} \mathrm{C} て ゙ 1$ 晚乾燥した。乾燥後, 乳鉢で粗粉砕し, 水素気流中 $250{ }^{\circ} \mathrm{C}$ で 1 時間, 更に $900{ }^{\circ} \mathrm{C}$ で 30 分熱処理して白 金とルテニウムを合金化して白金ルテニウム触媒を得た。

\section{2 触媒の物性分析}

貴金属含有率は灰化法によって分析した。触媒 $0.1 \mathrm{~g}$ を坩 堝に秤量し, $800{ }^{\circ} \mathrm{C}$ で数時間加熱することで触媒中のカーボ ンを燃焼させた後，䨌囲気炬にて水素気流中 $800{ }^{\circ} \mathrm{C}$ で 15 分間 加熱することで酸化物を金属に還元した．残渣を精秤し，投 入触媒量で除して貴金属含有率を求めた。白金含有率，ルテ ニウム含有率は，求めた貴金属含有率から白金とルテニウム の投入比から計算した。合金化状態は X 線回折装置（JDX8030，日本電子製）によって分析した。特性 X 線 CuKa $\alpha$ 用

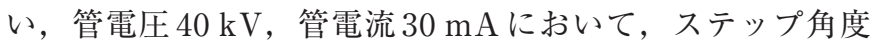
$0.02^{\circ}$ ，各ステップでの計数時間 2.5 秒で測定した。得られた ピーク（PtRu（220）面相当）とそのピークの半価幅から, 白金とルテニウムは均一分布していると仮定して, Scherrer

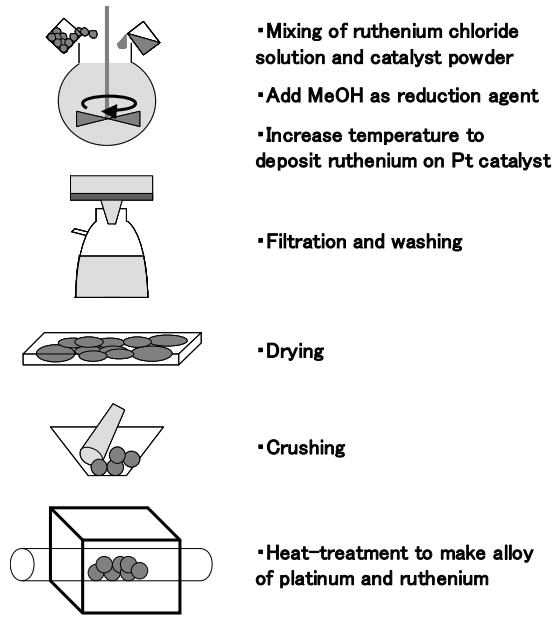

Fig. 1 Schematic flow of catalyst preparation.
の式より白金ルテニウムの粒子サイズを算出した。また，分 散状態は透過電子顕微鏡（JEM-2010，日本電子製）にて形 態観察した。

\section{3 一酸化炭素酸化ピーク測定}

2. 3. 1 カーボンペーパーの撥水化テトラフルオロ エチレンーヘキサフルオロプロピレン共重合体 (FEP) 分散 液（FEP-120J，三井デュポンフロロケミカル製）を蒸留水 で希釈し FEP $12.4 \%$ 分散液を得た。カーボンペーパー (TGP-H-120，東レ製）をそのFEP分散液に30分浸漬した後 $120{ }^{\circ} \mathrm{C}$ で 30 分乾燥した。 3 回浸漬，乾燥を繰り返した後， 2 -プロパノールで余分な FEPを洗い流して乾燥し，その後 $345{ }^{\circ} \mathrm{C}$ にて 20 分焼成して，約 $30 \%$ の FEPを含侵した撥水化 カーボンペーパーを得た。

2. 3.2 ハーフセル用 Ionomer/CBペースト, 触媒ペー ストの作製 Nafion ${ }^{\circledR} 5 \%$ 溶液 (DuPont製) をスプレー ドライ装置（GS310，ヤマト科学製）で， $120{ }^{\circ} \mathrm{C}$ のャンバ 一設定温度にて窒素中でスプレードライすることによって Ionomer 粉末を得た. その後, $1 \mathrm{~g}$ のカーボン（ケッチェン ブラック EC300J, ケッチェンブラックインターナショナル 製)，0.8 gの Ionomer 粉末， $4 \mathrm{~mL}$ の蒸留水， $4 \mathrm{~mL}$ の 1 - プロ パノール， $4 \mathrm{ml}$ の 2 -プロパノール，および， $200 \mathrm{~g}$ の $5 \mathrm{~mm} \phi$ ジルコニアボールをジルコニア製容器 $(250 \mathrm{cc})$ に投入した. そして，遊星ボールミル装置（LP-4，伊藤製作所製）を用い， 自転と公転比 1：1にて $200 \mathrm{rpm}$ にて 50 分粉砕混合して, Ionomer/CBペースト (Ionomer $/ \mathrm{CB}=40 / 50$ (wt\%比)）を 作製した.

触媒ペーストは，カーボン量 $1 \mathrm{~g}$ の触媒に蒸留水 $8.5 \mathrm{ml}$ を 用い十分に触媒を湿らせた後, $8.5 \mathrm{~mL}$ の 1 -プロパノール, $8.5 \mathrm{~mL}$ の 2-プロパノール, および, Ionomer 粉末 $1.2 \mathrm{~g}$ を加 えて, Ionomer/CB ペーストと同一条件の遊星ボールミルに て粉砕混合して作製した。

2. 3 . 3 ハーフセル用電極作製～バーコーター（K202，松尾産業製）を用い，No.9 のバー番手で撥水化処理を 施したカーボンペーパーに, Ionomer/CBペーストを塗布し た. 湿潤状態の塗膜厚は約 $120 \mu \mathrm{m}$ であった. $60{ }^{\circ} \mathrm{C} に て 5$ 分 乾燥後, $130{ }^{\circ} \mathrm{C}, 20 \mathrm{~kg} / \mathrm{cm}^{2}$ にて 1 分ホットプレスした。そ の後，触媒ペーストを同様の手法で白金量が $0.56 \mathrm{mg} / \mathrm{cm}^{2}$ に なるように塗布した．白金量は塗布回数とバー番手で制御し た.なお，塗布毎にホットプレスした。

2. 3.4 一酸化炭素酸化ピーク測定 得られたハーフ セル用電極から $4 \mathrm{~cm} \phi$ の電極を切り出し, Fig. 2 に示す半電

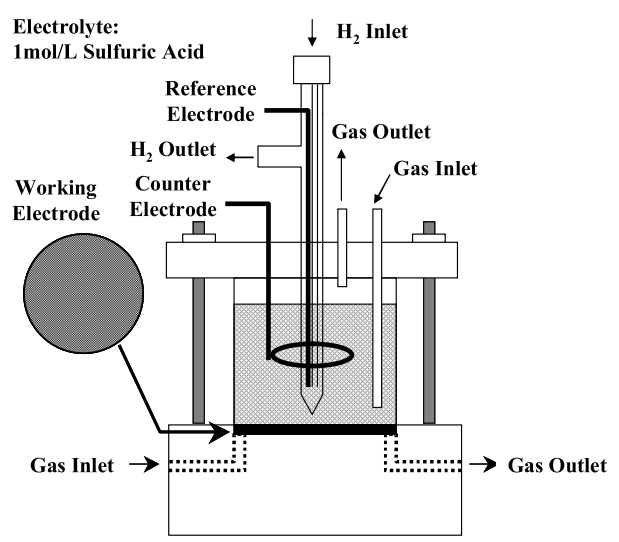

Fig. 2 Schematic design of half cell assembly. 
池セルに組み込んだ（有効反応面積 $3 \mathrm{~cm} \phi$ ). 電気化学的な 表面クリーニング後, $38^{\circ} \mathrm{C}$, 電位 $100 \mathrm{mV}$ （vs.RHE）で, $1 \%$ CO を混合した窒素を溶液中と電極下部に設けたガス 溝より電極部に供給した。15分後， $100 \mathrm{mV}$ から $1000 \mathrm{mV}$ ま で30 mV/secにて電位を掃引し，一酸化炭素酸化ピークを 測定した。

\section{4 シングルセル用電極の作製}

2. 4. $1 \mathrm{FEP} / \mathrm{CB}$ ペースト, シングルセル用Ionomer $/ \mathrm{CB}$ ペースト，触媒ペーストの作製 $2 \mathrm{~g}$ のカーボン（試作 品, 電気化学工業製), $5.45 \mathrm{~g}$ の FEP 分散液, $30 \mathrm{~mL}$ の蒸留 水, $15 \mathrm{~mL}$ の1-プロパノール, $15 \mathrm{ml}$ の2-プロパノールを前 記同様にして遊星ボールミルにて50分粉砕混合して $\mathrm{FEP} / \mathrm{CB}$ ペースト（FEP/CB = 60/40（wt\%比）を作製した また，ハーフセル用Ionomer/CBペースト，および，触媒ぺ ーストと同様の手順にて，1 g のカーボン量に対して Ionomer 粉末量をそれぞれ $1.2 \mathrm{~g}$ ，および， $1.6 \mathrm{~g}$ としてペー ストを作製し，シングルセル用 Ionomer/CB (Ionomer/CB = 60/50 (wt \% 比) ) ペースト，および，触媒ペーストを得た。 な押， CB：Ionomer 比を変更する場合は，適宜 Ionomer 粉 末量を変更した。

2. 4. 2 Ionomer $/ \mathrm{CB}$ 層\&撥水層（FEP/CB 層）付きカ ーボンペーパー作製バーコーターを用い, $\mathrm{FEP} / \mathrm{CB}$ ペーストをカーボンペーパー（TGP-H-120，東レ製）にバー 番手 8 番で塗布した。湿潤状態の塗膜厚は約 $100 \mu \mathrm{m}$ であっ た. $100{ }^{\circ} \mathrm{C}$ で 30 分乾燥後, $345{ }^{\circ} \mathrm{C}$ で 20 分焼成して, 撥水層付 きカーボンペーパーを作製した。その後，シングルセル用 Ionomer/CBペーストをバー番手 4 番で塗布した．湿潤状態 の塗膜厚は約 $40 \mu \mathrm{m}$ であった. $60{ }^{\circ} \mathrm{C} て ゙ 5$ 分乾燥後, $130{ }^{\circ} \mathrm{C}$, $20 \mathrm{~kg} / \mathrm{cm}^{2}$ にて1分ホットプレスして, Ionomer/CB 層\&撥 水層付きカーボンペーパーを作製した.

2. 4. 3 Catalyst Coated Substrate (CCS) タイプ触媒 層の作製触媒層作製のフロー図をFig. 3 に示す。 Ionomer/CB 層\&撥水層付きカーボンペーパーに, 触媒ペー ストをNo.6のバー番手で塗布した。湿潤状態の塗膜厚は約 $60 \mu \mathrm{m}$ であった. $60^{\circ} \mathrm{C}$ に 5 分乾燥後, $130^{\circ} \mathrm{C}, 20 \mathrm{~kg} / \mathrm{cm}^{2}$ にて 1 分ホットプレスした。同様にして, 塗布を繰り返し, 触媒量を塗布回数とバー番手で制御し，白金量で 0.28 $\mathrm{mg} / \mathrm{cm}^{2}$ とした。 なお, 塗布毎にホットプレスした. 以降, 得られた触媒層をCCS タイプ触媒層と呼ぶ。

2. 4. 4 Catalyst Coated Membrane (CCM) タイプ触

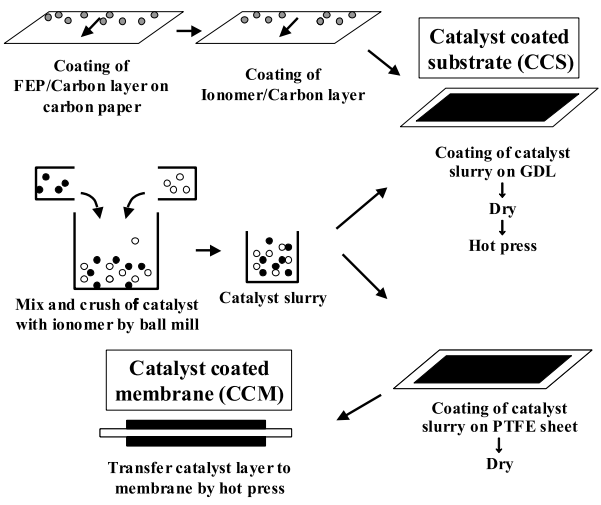

Fig. 3 Schematic flow of CCS and CCM preparation. 媒層の作製＼cjkstart厚み $0.3 \mathrm{~mm}$ のポリテトラフルオロエチレ ンシートに，触媒ペーストをNo. 8 のバー番手で塗布した。 湿潤状態の塗膜厚は約 $100 \mu \mathrm{m}$ であった. $60^{\circ} \mathrm{C} て ゙ 5$ 分乾燥後, Nafion ${ }^{\circledR} 112$ 膜（DuPont 製）にホットプレスで転写して，触 媒層付き膜（以降，CCMタイプ触媒層と呼ぶ）を作製した ${ }^{34)}$. 転写条件は $130{ }^{\circ} \mathrm{C}, 20 \mathrm{~kg} / \mathrm{cm}^{2}$ にて 30 分とした。白金量は 0.2 〜 $0.22 \mathrm{mg} / \mathrm{cm}^{2}$ であった.

\section{5 触媒層中の Ionomer 量が耐一酸化炭素被毒特性に} 与える影響

白金：ルテニウム $=1 ： 1.5$ の触媒を用い, $\mathrm{CB} ：$ Ionomer 比を $1 ： 0.8 \sim 1 ： 1.6$ の範囲のCCS タイプ触媒層, CCM 夕 イプ触媒層をそれぞれ作製した。CCSタイプ触媒層の場合は それら触媒層を直接アノードとし, CCM タイプ触媒層の場 合はそれら触媒層を撥水層付きカーボンペーパーと接合して アノードとした。そして，カソードに白金 $46.5 \mathrm{wt}$ \%\%触媒 （TEC10E50E，田中貴金属工業製）を用いたCCSタイプ触 媒層, 電解質膜に Nafion ${ }^{\circledR} 112$ を用いて，一本溝サーペンタイ ン流路付きセパレータで締め付けて, シングルセルを準備し た。水素/酸素を用いて十分に発電を繰り返して性能が安定

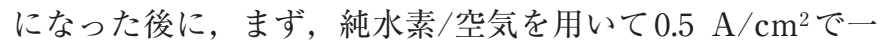
晚放置し，電圧が安定することを確認した。セル温度 $70{ }^{\circ} \mathrm{C}$, アノード露点 $70{ }^{\circ} \mathrm{C}$, カソード露点 $50{ }^{\circ} \mathrm{C}$, アノード利用率 $70 \%$, カソード利用率 $30 \%$ にて, ガス出口を大気圧開放に て発電試験を行った。電圧が安定したことを確認後，アノー ドガスを純水素から改質模擬ガス $\left(75 \% \mathrm{H}_{2}+25 \% \mathrm{CO}_{2}+\right.$ $100 \mathrm{ppmCO}$ ）に切り替えて，七ル電圧の変化を測定した. セル電圧が一定の挙動を示すところまでデー夕を取得し, 測 定終了とした.

\section{6 白金：ルテニウム組成比の耐一酸化炭素被毒特性} に与える影響

白金：ルテニウム $=1 ： 1.0 \sim 1 ： 3.0$ の触媒を用い, $\mathrm{CB}$ : Ionomer 比を $1 ： 1.6$ としたCCSタイプ触媒層を作製 した。なお，本実験では $\mathrm{Pt}$ 量を $0.56 \mathrm{mg} / \mathrm{cm}^{2}$ で一定とした. それら触媒層をアノードとして, 前述と同じ方法で耐一酸化 炭素被毒特性の発電試験を行った。な扔, 七ル温度を $50{ }^{\circ} \mathrm{C}$ $\sim 70{ }^{\circ} \mathrm{C}$ とて評価した. $60^{\circ} \mathrm{C}$ ではアノード露点 $60^{\circ} \mathrm{C}$, カソ ード露点 $45^{\circ} \mathrm{C}, 50{ }^{\circ} \mathrm{C}$ ではアノード露点 $50{ }^{\circ} \mathrm{C}$, カソード露点 $40{ }^{\circ} \mathrm{C}$ とた.

2. 7 エアーブリーディング下における白金：ルテニウ 么組成比の耐一酸化炭素被毒特性に与える影響

白金：ルテニウム $=9 ： 1 \sim 1 ： 1.5$ の触媒を用い, $\mathrm{CB}$ ： Ionomer 比を $1 ： 1.6$ としたCCSタイプ触媒層を作製した. なお，本実験ではPt量を $0.28 \mathrm{mg} / \mathrm{cm}^{2}$ とした。 そして，七 ル温度を $50{ }^{\circ} \mathrm{C}$ にて耐一酸化炭素被毒特性を評価した。改質 模擬ガスに切り替えて電圧変化の挙動を測定後, アノードに 空気を $1 \%$ 添加し，電圧の変化を測定した。電圧が安定する のを待ち, 順次アノードの空気添加量を増やし， $4 \%$ 空気添 加までの電圧変化を測定した。

\section{8 ハーフセルにおける触媒の安定性の調査}

2. 8. 1 初期の耐一酸化炭素被毒特性測定

前述の 白金：ルテニウム $=1 ： 1 \sim 1 ： 2$ の触媒のハーフセル用電 極を用い，Fig. 2 に示すハーフセルで耐一酸化炭素被毒特性 を評価した。ハーフセルに窒素を $20 \mathrm{~mL} / \mathrm{min}$ で供給して $60^{\circ} \mathrm{C}$ とし, その後, 供給ガスを純水素 $(100 \mathrm{~mL} / \mathrm{min})$ に切 り替え, 電流一定モードにて $0 \sim 500 \mathrm{~mA} / \mathrm{cm}^{2}$ まで水素酸化 
Table 1 Comparison of catalyst characterization.

\begin{tabular}{|c|c|c|c|c|c|c|c|c|}
\hline \multirow{2}{*}{$\begin{array}{l}\text { Ratio of } \\
\mathrm{Pt}: \mathrm{Ru}\end{array}$} & Pt wt $\%$ & Ru wt $\%$ & $\begin{array}{l}\text { Metal } \\
\text { wt } \%\end{array}$ & Peak angle $* 1$ & FWHM $* 1$ & $\begin{array}{l}\text { Paticle size } \\
\text { by XRD }\end{array}$ & $\begin{array}{c}\text { Surface area } \\
\text { by BET }\end{array}$ & $\begin{array}{c}\text { Surface area } \\
\text { by BET }\end{array}$ \\
\hline & wt $\%$ & wt $\%$ & $\mathrm{wt} \%$ & $\circ$ & $\circ$ & $\mathrm{nm}$ & $\mathrm{m}^{2} / \mathrm{g}$-Cat & $\mathrm{m}^{2} / \mathrm{g}$-Carbon \\
\hline $9: 1$ & 38.9 & 2.2 & 41.1 & 67.72 & 2.36 & 4.1 & 429.9 & 730.0 \\
\hline $6: 1$ & 38.5 & 3.3 & 41.8 & 67.80 & 2.53 & 3.8 & 416.0 & 714.9 \\
\hline $4: 1$ & 37.4 & 4.9 & 42.4 & 67.94 & 2.58 & 3.7 & 441.0 & 765.5 \\
\hline $3: 1$ & 38.5 & 6.7 & 45.2 & 68.06 & 2.50 & 3.8 & 406.9 & 741.9 \\
\hline $2: 1$ & 37.0 & 9.6 & 46.6 & 68.44 & 2.65 & 3.6 & 423.4 & 792.2 \\
\hline $1: 1$ & 32.6 & 16.9 & 49.5 & 68.86 & 3.05 & 3.2 & 402.2 & 796.4 \\
\hline $1: 1.5$ & 29.8 & 23.2 & 53.0 & 68.92 & 2.59 & 3.7 & 370.0 & 787.1 \\
\hline $1: 2$ & 27.6 & 28.7 & 56.3 & 69.06 & 2.38 & 4.1 & 338.2 & 773.9 \\
\hline $1: 2.5$ & 25.7 & 33.3 & 59.0 & 69.11 & 1.88 & 5.1 & 319.2 & 778.5 \\
\hline $1: 3$ & 24.6 & 38.3 & 62.9 & 69.34 & 1.65 & 5.9 & 265.9 & 716.6 \\
\hline
\end{tabular}

$※ 1$. Peak angle and FWHM (full width of half maximum intensity) were obtained from XRD profile of PtRu (220) plane.

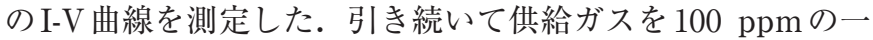
酸化炭素を含む水素 $(100 \mathrm{~mL} / \mathrm{min})$ に切り替え，同様に， 一酸化炭素存在下での水素酸化のI-V曲線を測定した。

\subsection{2 触媒劣化加速試験}

初期の耐一酸化炭素被毒特性の測定終了後，供給ガスを窒 素 $(20 \mathrm{~mL} / \mathrm{min})$ に切り替え，セル温度を $50{ }^{\circ} \mathrm{C}$ とた。そ の後，保持電位の検討では，電極電位を，それぞれ $300 \mathrm{mV}$, $600 \mathrm{mV}, 900 \mathrm{mV}, 1000 \mathrm{mV}$ ，および，1100 mmV（vs. RHE）で 18 時間保持した。電位掃引幅の検討では，電極電 位を，下限電位 $10 \mathrm{mV}$ ，上限電位をそれぞれ $300 \mathrm{mV}, 600$ $\mathrm{mV}, 900 \mathrm{mV}, 1000 \mathrm{mV}$ ，および $1100 \mathrm{mmV}$ (vs. RHE) と し， $50 \mathrm{mV} / \mathrm{sec}$ で 18 時間掃引した。その後，セル温度を $60{ }^{\circ} \mathrm{C}$ とし, 供給ガスを再び純水素 $(100 \mathrm{~mL} / \mathrm{min})$ に切り替 え， 0〜 $500 \mathrm{~mA} / \mathrm{cm}^{2}$ まで水素酸化の I-V 曲線を測定した。 引き続き，供給ガスを $100 \mathrm{ppm}$ の一酸化炭素を含む水素 (100 mL/min) に切り替え, 同様にして, 一酸化炭素存在下 での水素酸化の I-V 曲線を測定した。

\section{1 触媒の物性解析}

\section{3 結果と考察}

Table 1 に作製した触媒の白金含有率，ルテニウム含有率, 貴金属含有率，X線回折におけるピーク位置および半価幅， それらから求めた粒子サイズ，および，窒素BET吸着によ る触媒表面積值をまとめた。白金触媒にルテニウムを加えた ために，ルテニウム比率が高くなるに従って，貴金属含有率 が高くなった．また，ルテニウム比率の増加に従いX $\mathrm{X}$ 線回折 におけるピーク角度が高角度側へシフトし, 触媒粒子サイズ が大きく, また, 単位重量あたりの触媒表面積值 $\left(\mathrm{m}^{2} / \mathrm{g}-\right.$ Cat.）が小さくなった。単位重量あたりの触媒表面積 $\left(\mathrm{m}^{2} / \mathrm{g}\right.$-Cat.) は主にカーボン表面積由来の值であると考えら れるが，投入ルテニウム量の増加に従って貴金属含有率が高 くなったため，分母が大きくなり小さくなったと考えられる。 単位カーボン量あたりの触媒表面積值 $\left(\mathrm{m}^{2} / \mathrm{g}\right.$-Carbon) は, ルテニウム量にほとんど依存しなかったことから，投入ルテ ニウム量がカーボンの状態に変化を与えていないことが示唆 される，今回は原料物質の白金触媒を固定して触媒試作をし
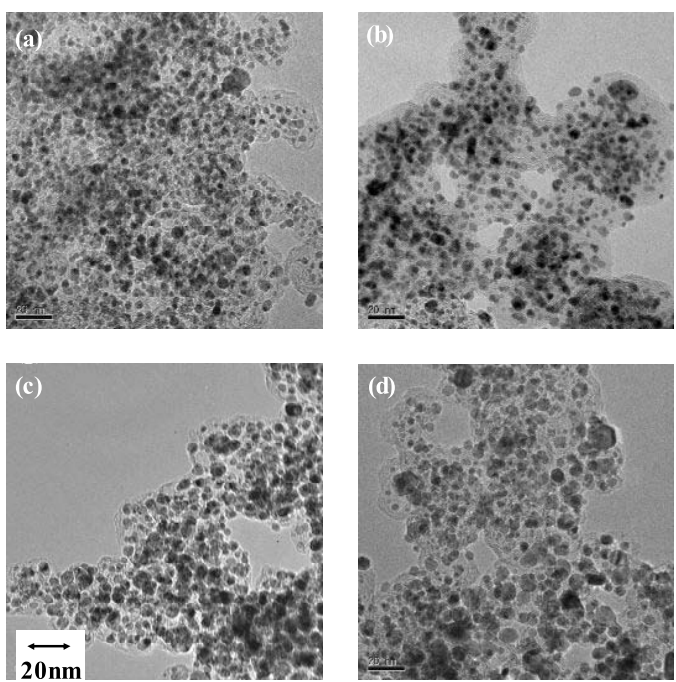

Fig. 4 Transmission electron micrograph of platinumruthenium catalyst of (a) $\mathrm{Pt}: \mathrm{Ru}=1: 1$ (b) $\mathrm{Pt}: \mathrm{Ru}=1$ : 1.5 (c) $\mathrm{Pt}: \mathrm{Ru}=1: 2$ (d) Pt $: \mathrm{Ru}=1: 2.5$.

たため，貴金属含有率，粒子径などに若干の違いが生じた. しかし, 燃料電池反応は白金上でのみ起こることから, 白金 とルテニウム比の比較の実験は白金量基準ですべきと考えら れ, 白金触媒を固定すると, 電極中の厚みを担うカーボン量 も一定で評価することができる.よって, 電極構造の触媒層 特性への影響をより小さくできると判断した。

Fig. 4 に白金：ルテニウム $=1 ： 1 ， 1 ： 1.5,1 ： 2$, $1 ： 2.5$ の透過電子顕微鏡写真を示す.ルテニウム量の増加 に従って, 触媒の分散性が悪くなり, 触媒粒子サイズが大き くなる傾向を示した. 白金：ルテニウム $=1$ ：1の粒子径は $4 \sim 5 \mathrm{~nm}, 1 ： 2$ の場合は $6 \sim 8 \mathrm{~nm}$ であった. Schmidt らのコロイド保護剤を用いた手法での白金ルテニウム触媒の 粒子サイズは 2 〜 nmであり ${ }^{25)}$, Giorgi らが白金ルテニウ ムの組成検討に用いた白金ルテニウム触媒の粒子サイズは 2 $\mathrm{nm}$ 程度で ${ }^{19)}$, 今回試作した触媒は総じてそれより大きかっ た. 粒子サイズには担持率や担体種などの物理的なパラメー ターも影響を与えていると考えられるが，今回の処理で用い 
た高温での加熱処理がその差の一要因になっていると推測さ れる.

Fig. 5 に白金：ルテニウム $=3 ： 1$ から $1 ： 3$ の $30^{\circ}$ 〜 $50^{\circ}$ のX線回折を示す。作製した触媒は白金単独のピークが ルテニウムの添加によってシフトした．よって，合金化して いる触媒となっていることがわかった。また，白金：ルテニ ウム $=3 ： 1 \sim 1 ： 1.5$ までの範囲は白金の面心立方格子の み検出され，ルテニウム比の増加に従いピークがより高角度 側にシフトしたことから，ルテニウムの固溶量が増加してい ることが確認された．白金：ルテニウム $=1 ： 2$ と $1 ： 2.5$ では，結晶相は白金の面心立方格子とルテニウムの六方最密 格子の 2 相であった．白金：ルテニウム $=1 ： 3$ では若干の 白金の面心立方格子の存在も確認できたが，ほとんどがルテ ニウムの六方最密格子であった.

Fig. 6に白金：ルテニウム比 $=2 ： 1 \sim 1 ： 2$ の触媒での 一酸化炭素酸化ピークを示す．比較のために白金触媒の一酸 化炭素酸化ピークも合わせて記載した。白金触媒の場合には 一酸化炭素酸化ピークが $880 \mathrm{mV}$ （vs. RHE）と最も高い電 位となり，ルテニウムの添加は一酸化炭素酸化ピーク電位を

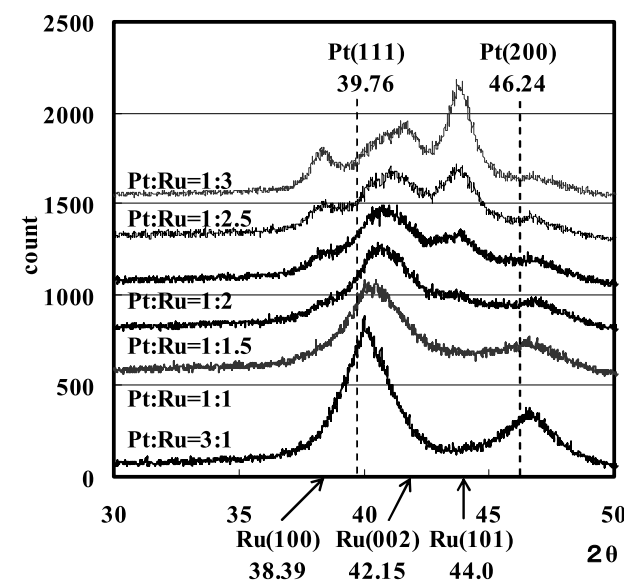

Fig. 5 XRD profile of platinum-ruthenium catalyst of from $\mathrm{Pt}: \mathrm{Ru}=1: 3$ to $\mathrm{Pt}: \mathrm{Ru}=3: 1$.

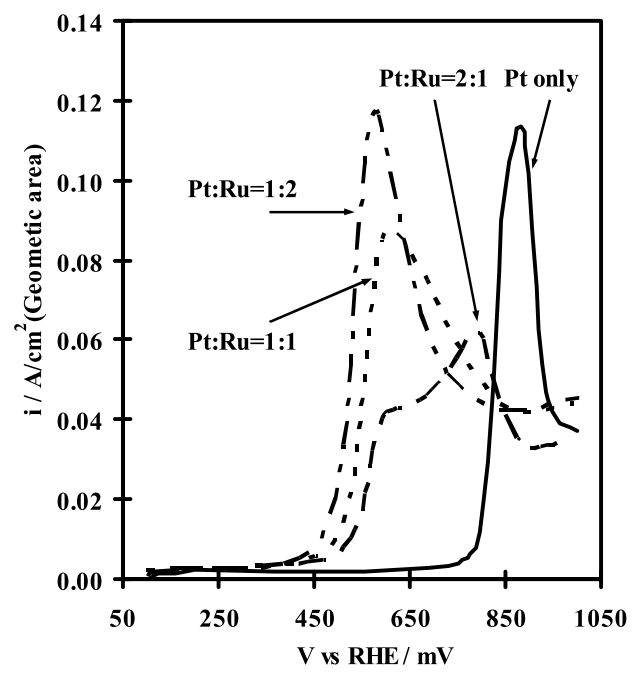

Fig. 6 CO stripping chart of platinum-ruthenium catalyst of from $\mathrm{Pt}: \mathrm{Ru}=2: 1$ to $\mathrm{Pt}: \mathrm{Ru}=1: 2$ with a comparison of that of $\mathrm{Pt}$ only catalyst. Measurement temperature : $38^{\circ} \mathrm{C}$, electrolyte : $1 \mathrm{~mol} / \mathrm{L} \mathrm{H}_{2} \mathrm{SO}_{4}$, sweep rate : $30 \mathrm{mV} / \mathrm{sec}$.
低電位にシフトさせた. 白金：ルテニウム $=2 ： 1$ では複数 のピークの重なりとなっていることが推測され，他のピーク と比較して, ルテニウムが十分に固溶した面と, 白金リッチ な面の複数の表面が存在していることが示唆される。ルテニ ウム比が高くなるに従って，ピークが低電位側にシフトし， 白金：ルテニウム＝1：1ではピーク位置は $610 \mathrm{mV（vs.}$ RHE）となり, 白金：ルテニウム $=1 ： 2$ では $580 \mathrm{mV}$ (vs. RHE）となった. Russellらの用いた白金：ルテニウム = 1：1の粉末触媒では, 一酸化炭素酸化ピーク位置は 480 $\mathrm{mV}$ (vs. RHE) であり 20)，また，Shumidtら 25)，および, Giorgi ら 19) の用いた触媒の一酸化炭素酸化ピーク位置はそ れぞれ， $570 \mathrm{mV}$ (vs. RHE)，および， $740 \mathrm{mV}$ (vs. RHE) であった。このように触媒の調製方法によって，同じ白金と ルテニウム組成でも異なる一酸化炭素酸化ピーク位置を示す ことがわかるが，今回試作した触媒の一酸化炭素酸化ピーク 位置は既報と同等範囲であった。

\section{2 触媒層中のIonomer 量が耐一酸化炭素被毒特性に} 与える影響

Fig. 7 にCCS タイプ触媒層を用いた場合の，耐一酸化炭素 被毒特性に与える触媒層中のカーボンと Ionomer 比の影響を 示す. $\mathrm{CB}$ : Ionomer $=1 ： 1.4 \sim 1 ： 1.8$ に扔いて耐一酸化 炭素被毒特性に大きな差は見られず，評価条件における低下 電圧はいずれも約 $40 \mathrm{mV}$ だった. Ionomer 量が極端に多い 場合や，少ない場合の挙動はこれとは異なることが推測され るが，耐一酸化炭素被毒特性に，この範囲の Ionomer 量の変 更は大きく影響を与えないことがわかった。また，一酸化炭 素導入後でも, 特に電圧の振動等なく安定して測定すること ができた。

Fig. 8にCCM タイプ触媒層を用いた場合の, 耐一酸化炭 素被毒特性に与える触媒層中のカーボンとIonomer 比の影 響を示す.CCSタイプ触媒層の場合と同等のカーボン/ Ionomer 比の CB： Ionomer $=1 ： 1.4$ および $1 ： 1.6$ の場合 には，一酸化炭素導入後に大きな電圧振動が見られた。 $\mathrm{CB}:$ Ionomer = $1: 1.2$ 以下の Ionomer 比になると一酸化炭 素導入後の電圧が安定になり, $\mathrm{CB}:$ Ionomer $=1 ： 1.2 \sim$ 1：0.8の範囲では耐一酸化炭素被毒特性に大きな差は見られ

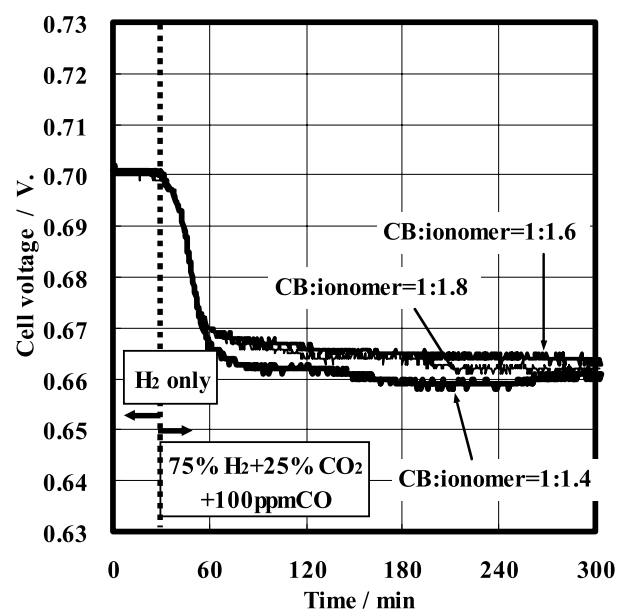

Fig. 7 Change in cell voltage when fuel is changed from pure $\mathrm{H}_{2}$ to mixed fuel of $75 \% \mathrm{H}_{2}+25 \% \mathrm{CO}_{2}+100 \mathrm{ppmCO}$ in the case of CCS-type catalyst layer. Cell temperature : $70{ }^{\circ} \mathrm{C}$, current density : $0.5 \mathrm{~A} / \mathrm{cm}^{2}$, Pt loading of anode $: 0.28 \mathrm{mg} / \mathrm{cm}^{2}$. 
ず，評価条件における低下電圧は 50 〜 $56 \mathrm{mV}$ だった。 Ionomer が過剩な場合の電圧の振動は, Ionomer が過剩故に 触媒層内の電子導電性の欠落が生じ, 結果として有効触媒表 面積が減少したことによって生じたものと推測した。

Table 2にCCSタイプ触媒層を用いた場合，および，CCM タイプ触媒層を用いた場合の, 純水素から一酸化炭素を含ん だ改質模擬ガスに切り替えた際の電圧の変化を，カーボン /Ionomer 比でまとめた. Table 2からCCSタイプ触媒層と CCM タイプ触媒層で, 耐一酸化炭素被毒特性を最大に発揮 するカーボン/Ionomer 比の最適值が異なることがわかる. これは同じ触媒，同じ触媒ペーストを用いた場合でも，触媒 層の形成の仕方によりカーボン/Ionomer 比の最適值が異な る場合のあることを示す。最適組成のカーボン/Ionomer 比 では，CCS夕イプ触媒層の方が低下電圧が小さかった。これ は，CCS タイプ触媒層の方が若干触媒量が多いことに起因し ている可能性があり，最適化後の耐一酸化炭素被毒特性には 触媒層タイプの差はないと考えられる. Fig. 9にCCSタイプ 触媒層と CCM タイプ触媒層の表面を実体顕微鏡で撮影した 写真を示す.Fig. 9に示されたように，CCSタイプ触媒層表 面には触媒層を塗布する前の基材表面由来と思われるクラッ クが多数見られたのに対して，CCMタイプ触媒層表面は滑

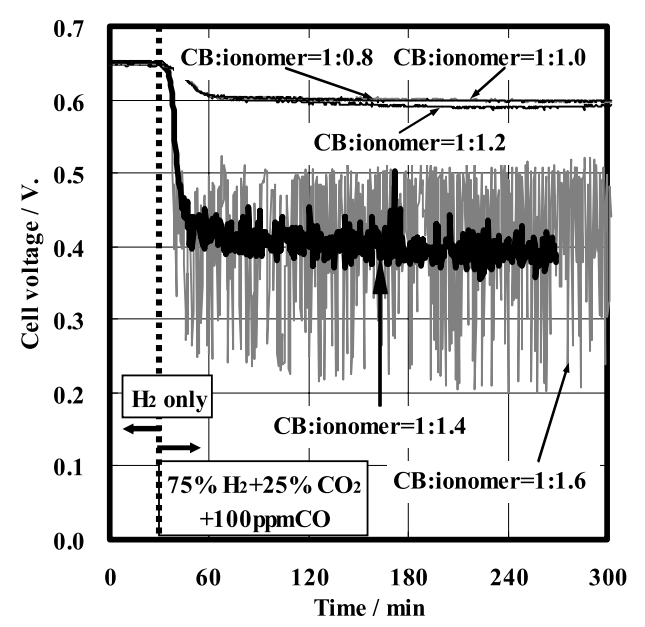

Fig. 8 Change in cell voltage when fuel is changed from pure $\mathrm{H}_{2}$ to mixed fuel of $75 \% \mathrm{H}_{2}+25 \% \mathrm{CO}_{2}+100 \mathrm{ppmCO}$ in the case of CCM-type catalyst layer. Cell temperature : $70{ }^{\circ} \mathrm{C}$, current density : $0.5 \mathrm{~A} / \mathrm{cm}^{2}$, Pt loading of anode : $0.20 \sim 0.22 \mathrm{mg} / \mathrm{cm}^{2}$.

Table 2 Dropping voltage caused by $\mathrm{CO}$ when fuel is changed from pure $\mathrm{H}_{2}$ to mixed fuel of $75 \% \mathrm{H}_{2}+25 \%$ $\mathrm{CO}_{2}+100 \mathrm{ppmCO}$ in the case of platinum-ruthenium catalyst of $\mathrm{Pt}: \mathrm{Ru}=1: 1.5$. Cell temperature : $70{ }^{\circ} \mathrm{C}$, current density : $0.5 \mathrm{~A} / \mathrm{cm}^{2}$, Pt loading of anode : 0.28 $\mathrm{mg} / \mathrm{cm}^{2}$ in the case of CCS-type catalyst layer. $0.20 \sim 0.22$ $\mathrm{mg} / \mathrm{cm}^{2}$ in the case of CCM-type catalyst layer.

\begin{tabular}{ccccccc}
\hline $\begin{array}{c}\text { Ratio of } \\
\text { CB }: \text { Ionomer }\end{array}$ & $1: 0.8$ & $1: 1.0$ & $1: 1.2$ & $1: 1.4$ & $1: 1.6$ & $1: 1.8$ \\
\hline CCM & 50 & 53 & 56 & $(260) * 1$ & $(300) * 2$ & - \\
\hline CCS & - & - & - & 39 & 39 & 38 \\
\hline
\end{tabular}

$※ 1$. There was a voltage oscillation between $220 \sim 280$. $※ 2$. There was a voltage oscillation between $140 \sim 450$.
らかな表面で，かつ，クラックは存在しなかった。このクラ ックの有無が触媒層中の細孔量に変化を与えて，最適な CB：Ionomer 比に影響を与えたと推測した。

\section{3 白金：ルテニウム組成比の耐一酸化炭素被毒特性} に与える影響

Fig. 10 に白金：ルテニウム $=1 ： 1$ の触媒を用いた時の 耐一酸化炭素被毒特性評価の結果を示す。純水素から一酸化 炭素を $100 \mathrm{ppm}$ 含んだ改質模擬ガスに切り替えた際の電圧低 下は，50 ${ }^{\circ} \mathrm{C}, 60^{\circ} \mathrm{C}, 70{ }^{\circ} \mathrm{C}$ で，それぞれ $234 \mathrm{mV}, 64 \mathrm{mV}, 33$ $\mathrm{mV}$ であり，七ル温度が上昇するに従って触媒の耐一酸化炭 素被毒が急激に減少した。Fig. 11 に白金：ルテニウム $=$ 1：20触媒を用いた時の耐一酸化炭素被毒特性評価の結果 を示す。一酸化炭素による電圧低下は， $50{ }^{\circ} \mathrm{C} ， 60{ }^{\circ} \mathrm{C} ， 70{ }^{\circ} \mathrm{C}$ で，それぞれ $100 \mathrm{mV}, 44 \mathrm{mV}, 20 \mathrm{mV}$ であり，こちらもセ ル温度が上昇するに従って触媒の耐一酸化炭素被毒が急激に 減少した. Fig. 10，11より，白金：ルテニウム $=1 ： 2$ の 触媒の方が全ての温度領域で高い耐一酸化炭素被毒特性を示 した. Fig. 12 に白金とルテニウムの組成比が一酸化炭素被
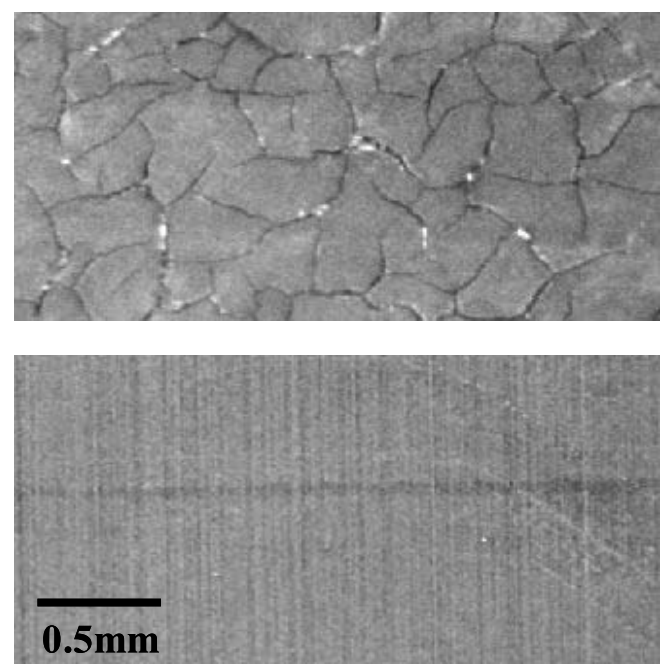

Fig. 9 Microscope photograph of surface of catalyst layer of (a) CCS-type catalyst layer (b) CCM-type catalyst layer.

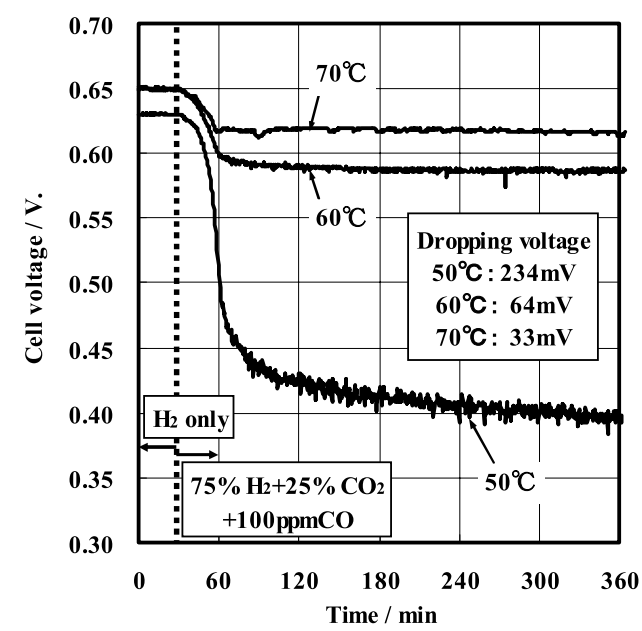

Fig. 10 Change in cell voltage when fuel is changed from pure $\mathrm{H}_{2}$ to mixed fuel of $75 \% \mathrm{H}_{2}+25 \% \mathrm{CO}_{2}+100 \mathrm{ppmCO}$ in the case of platinum-ruthenium catalyst of $\mathrm{Pt}: \mathrm{Ru}=1$ : 1. Cell temperature : 50,60 , and $70{ }^{\circ} \mathrm{C}$, current density : 0.5 $\mathrm{A} / \mathrm{cm}^{2}$, Pt loading of anode $: 0.56 \mathrm{mg} / \mathrm{cm}^{2}$. 


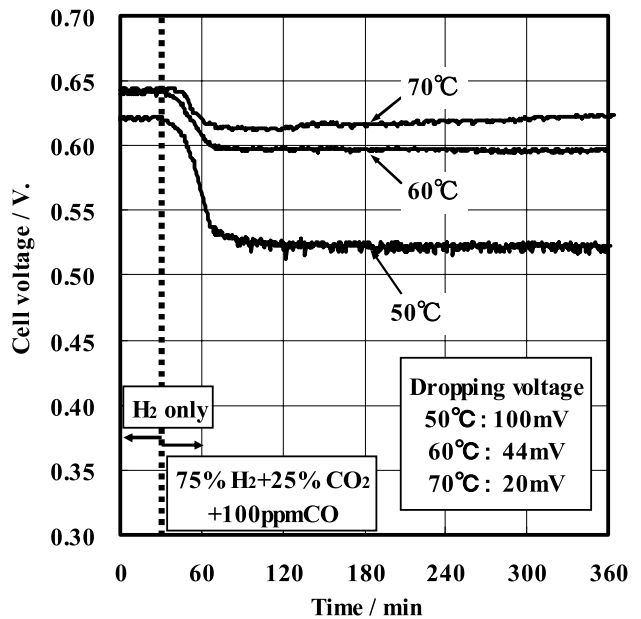

Fig. 11 Change in cell voltage when fuel is changed from pure $\mathrm{H}_{2}$ to mixed fuel of $75 \% \mathrm{H}_{2}+25 \% \mathrm{CO}_{2}+100 \mathrm{ppmCO}$ in the case of platinum-ruthenium catalyst of $\mathrm{Pt}: \mathrm{Ru}=1: 2$. Cell temperature : 50,60 , and $70^{\circ} \mathrm{C}$, current density : 0.5 $\mathrm{A} / \mathrm{cm}^{2}$, Pt loading of anode : $0.56 \mathrm{mg} / \mathrm{cm}^{2}$.

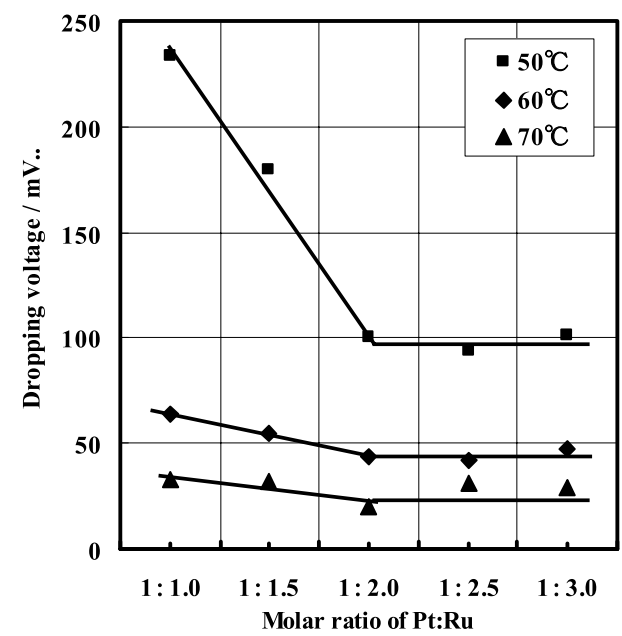

Fig. 12 Dropping voltage caused by $\mathrm{CO}$ when fuel is changed from pure $\mathrm{H}_{2}$ to mixed fuel of $75 \% \mathrm{H}_{2}+25 \%$ $\mathrm{CO}_{2}+100$ ppmCO in the case of platinum-ruthenium catalyst of from $\mathrm{Pt}: \mathrm{Ru}=1: 1.0$ to $\mathrm{Pt}: \mathrm{Ru}=1: 3.0$. Cell temperature : 50,60 , and $70{ }^{\circ} \mathrm{C}$, current density : 0.5 $\mathrm{A} / \mathrm{cm}^{2}$, Pt loading of anode : $0.56 \mathrm{mg} / \mathrm{cm}^{2}$.

毒による電圧低下に与える影響を示す。一酸化炭素被毒によ る電圧低下は, $50{ }^{\circ} \mathrm{C} \sim 70{ }^{\circ} \mathrm{C}$ のいずれの温度領域でも, 白 金：ルテニウム $=1 ： 1 \sim 1 ： 2$ の範囲はルテニウム比率が 高くなるに従って減少し, 白金：ルテニウム $=1 ： 2 \sim 1 ：$ 3 の範囲はほぼ定となった。特に, 耐一酸化炭素被毒の厳 しい条件下である低温で，その傾向は顕著となった．多くの 報告が耐一酸化炭素被毒特性は, 白金：ルテニウム $=1 ： 1$ の時に最大になったとの結果を報告しているが2,6,7,19,21)，今回 の結果はそれらとは異なった。この結果は一酸化炭素酸化ピ ークが白金：ルテニウム $=1 ： 2$ で最も低い電位を示したこ とと相関し, 本調製法の触媒では, 白金：ルテニウム $=1 ：$ 2 の時に最も高い耐一酸化炭素被毒特性を示したと考えてい る.

$\mathrm{X}$ 線回折の結果と比較してみると, 白金の面心立方格子の 中にルテニウムが固溶する過程では, 固溶量の増加に従って
Table 3 Comparison of dropping voltage caused by $\mathrm{CO}$ (cell voltage with pure $\mathrm{H}_{2}$ - cell voltage with mixed fuel of $\left.\mathrm{H}_{2}+\mathrm{CO}\right)$.

\begin{tabular}{ccc}
\hline Sorce & $\begin{array}{c}\text { Dropping } \\
\text { voltage } \\
(\mathrm{mV})\end{array}$ & $\begin{array}{c}\text { Conditions } \\
\text { Cell temp., Pt loading, } \\
\text { CO conc., CD }{ }^{* 1}\end{array}$ \\
\hline $\begin{array}{c}\text { This report } \\
(\mathrm{Pt}: \mathrm{Ru}=1: 2)\end{array}$ & 20 & $70^{\circ} \mathrm{C}, 0.56 \mathrm{mg} / \mathrm{cm}^{2}-\mathrm{Pt}$, \\
\hline Oetjen, et al & 100 & $80^{\circ} \mathrm{C}, 0.66 \mathrm{mg} / \mathrm{cm}^{2}-\mathrm{Pt}$, \\
$(\mathrm{Pt}: \mathrm{Ru}=1: 1)^{6)}$ & & $100 \mathrm{ppmCO}, 0.5 \mathrm{~A} / \mathrm{cm}^{2}$ \\
\hline Zawodzinski, et al & 150 & $80^{\circ} \mathrm{C}, 0.60 \mathrm{mg} / \mathrm{cm}^{2}-\mathrm{Pt}$, \\
$(\mathrm{Pt}: \mathrm{Ru}=1: 1)^{24)}$ & & $100 \mathrm{ppmCO}, 0.6 \mathrm{~A} / \mathrm{cm}^{2}$ \\
\hline $\begin{array}{c}\text { Iwase, } \text { et al } \\
(\mathrm{Pt}: \mathrm{Ru}=1: 1)^{21)}\end{array}$ & 13 & $80^{\circ} \mathrm{C}, 0.40 \mathrm{mg} / \mathrm{cm}^{2}-\mathrm{Pt}$, \\
\end{tabular}

$※ 1 . \mathrm{CD}=$ current density.

耐一酸化炭素被毒特性が向上し，一方，ルテニウムの六方最 密格子が認められる領域では，耐一酸化炭素被毒特性に差は 見られなかった。そのことから，白金の面心立方格子に固溶 したルテニウムが，白金の耐一酸化炭素被毒特性に強く関与 していることが示唆された.つまり, Watanabeらが “Bifunctional mechanism” で提唱するように ${ }^{4}$, 白金近傍に如 何に効率よくルテニウムを配置するかが耐一酸化炭素被毒特 性を決定付ける重要な因子となっていることがわかる.今回 のような触媒調製手法を用いた場合には，白金：ルテニウ ム = $1 ： 1$ ではルテニウムを十分に白金近傍に配置すること ができず，結果としてより多くのルテニウムを必要とした可 能性がある。一方，今回の結果では白金中心の面心立方格子 相とルテニウム中心の六方最密格子相で, 耐一酸化炭素被毒 特性に極端な差が見られなかったことから，結晶構造そのも のは耐一酸化炭素被毒特性を決定付ける重要因子ではないこ とがわかった. Table $3 に$ に, 今回の結果とこれまでに報告さ れた耐一酸化炭素被毒特性との結果を比較した，完全に同一 な発電条件での比較は難しいが, 評価条件などが比較的近い ところからのデータを参照した. 今回得られた耐一酸化炭素 被毒特性は, Iwase らの報告7,21) である触媒と同等の高い耐 一酸化炭素被毒特性を示した. Iwase らの記述によると， Iwase らの触媒には加熱処理が施してあり合金化が促されて いるとのことである. 今回の触媒も同様の処理を施してある ことから，高温での合金化処理が，耐一酸化炭素被毒特性を 向上させる重要な因子であることが示唆された.

3. 4 エアーブリーディング下における白金：ルテニウ 么組成比の耐一酸化炭素被毒特性に与える影響

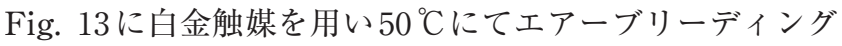
効果を測定した結果を示す.なお，白金担持量は $\mathrm{Pt}=0.28$ $\mathrm{mg} / \mathrm{cm}^{2}$ とした. 純水素から改質模擬ガスに切り替えると, 急激に一酸化炭素被毒によって大きな電圧低下があり, その 後一酸化炭素被毒によって電圧が振動し安定した電圧が得ら れなかった. 空気を $1 \%, 2 \%, 3 \%$ と添加するも電圧の振 動は収まらず，電圧も回復しなかった４％の空気を添加す ると電圧振動幅は幾分小さくなり, 電圧も回復する傾向を示 したが，安定した電圧を得ることができなかった．白金触媒 量を $\mathrm{Pt}=0.5 \mathrm{mg} / \mathrm{cm}^{2}$, 発電温度を $70{ }^{\circ} \mathrm{C}$ した場合では, 


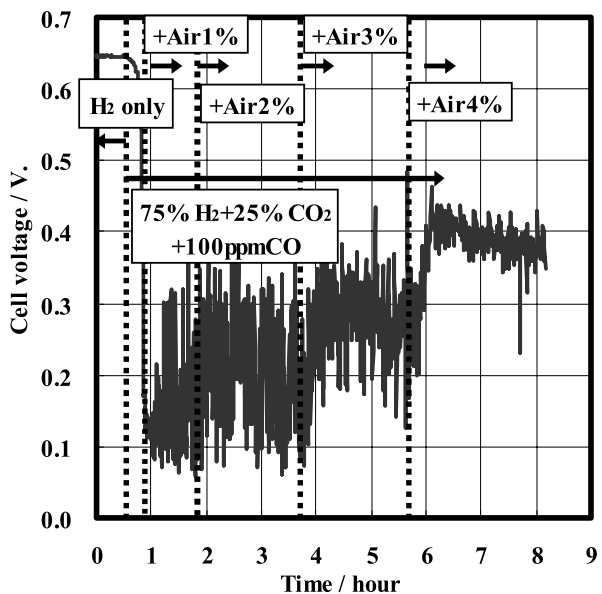

Fig. 13 Change in cell voltage when fuel is changed from pure $\mathrm{H}_{2}$ to mixed fuel of $75 \% \mathrm{H}_{2}+25 \% \mathrm{CO}_{2}+100 \mathrm{ppmCO}$, and to $75 \% \mathrm{H}_{2}+25 \% \mathrm{CO}_{2}+100 \mathrm{ppmCO}+1 \sim 4 \%$ air in the case of platinum only catalyst. Cell temperature : $50{ }^{\circ} \mathrm{C}$, current density : $0.5 \mathrm{~A} / \mathrm{cm}^{2}$, Pt loading of anode : 0.28 $\mathrm{mg} / \mathrm{cm}^{2}$.

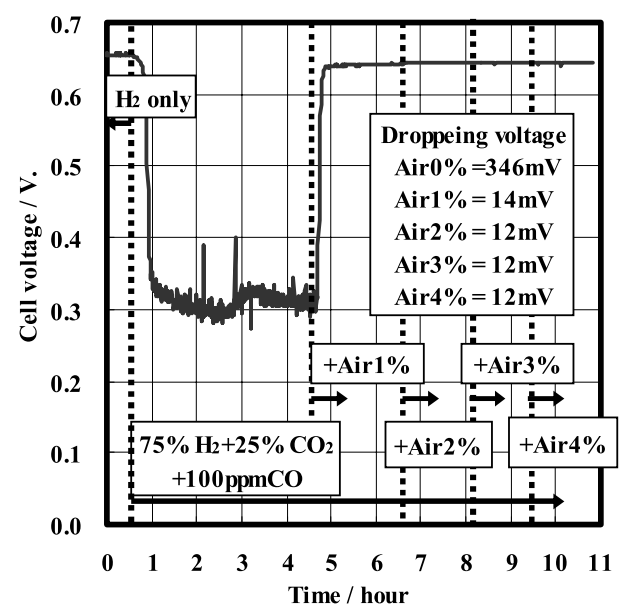

Fig. 14 Change in cell voltage when fuel is changed from pure $\mathrm{H}_{2}$ to mixed fuel of $75 \% \mathrm{H}_{2}+25 \% \mathrm{CO}_{2}+100 \mathrm{ppmCO}$, and to $75 \% \mathrm{H}_{2}+25 \% \mathrm{CO}_{2}+100 \mathrm{ppmCO}+1 \sim 4 \%$ air in the case of platinum-ruthenium catalyst of $\mathrm{Pt}: \mathrm{Ru}=2: 1$. Cell temperature : $50{ }^{\circ} \mathrm{C}$, current density : $0.5 \mathrm{~A} / \mathrm{cm}^{2}$, Pt loading of anode : $0.28 \mathrm{mg} / \mathrm{cm}^{2}$.

$1 \%$ 空気添加にて，一酸化炭素被毒は完全には回復せずも既 に電圧の振動は収まり，その後空気を $3 \%$ 添加すると一酸化 炭素被毒による電圧低下がほぼ完全に回復した。そのことか ら，エアーブリーディング運転での耐一酸化炭素被毒特性の 発現は，その発電条件，触媒量に大きく影響されることがわ かった．今回は，白金とルテニウム組成の影響を評価するた め，一般的に耐一酸化炭素被毒特性測定条件とされる測定条 件より, 少し厳しい測定条件として $\mathrm{Pt}=0.28 \mathrm{mg} / \mathrm{cm}^{2}$, 発電 温度 $50{ }^{\circ} \mathrm{C}$, CO濃度 $100 \mathrm{ppm}$ にて, ルテニウムの添加効果 を確認することとした。

Fig. 14 に白金：ルテニウム $=2 ： 1$ とした時の耐一酸化 炭素被毒特性に与えるエアーブリーディングの効果を示す。 CO $100 \mathrm{ppm}$ 含む改質模擬ガスに切り替えた途端に大きな 電圧低下を確認したが，その後 $1 \%$ の空気添加で性能が回復 し, 一酸化炭素被毒による性能低下はほとんど無視できる範

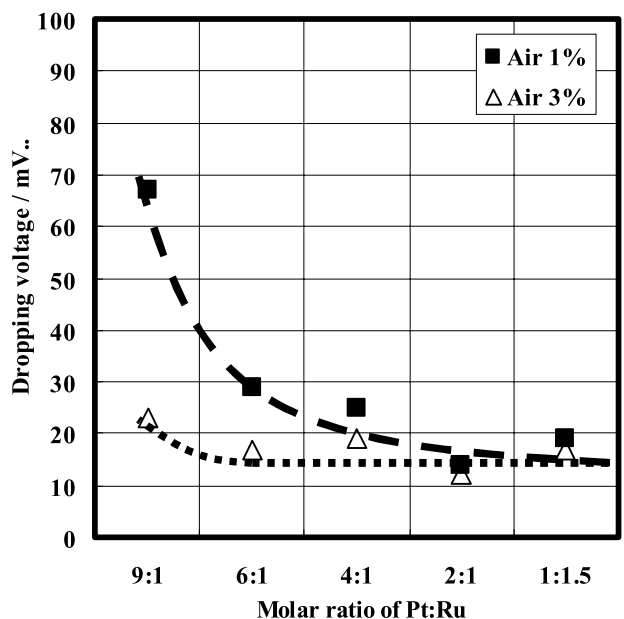

Fig. 15 Dropping voltage caused by $\mathrm{CO}$ when fuel is changed from pure $\mathrm{H}_{2}$ to mixed fuel of $75 \% \mathrm{H}_{2}+25 \%$ $\mathrm{CO}_{2}+100 \mathrm{ppmCO}+$ air $1 \%$ or + air $3 \%$ in the case of platinum-ruthenium catalyst of from $\mathrm{Pt}: \mathrm{Ru}=9.1$ to $\mathrm{Pt}$ : $\mathrm{Ru}=1: 1.5$. Cell temperature $: 50{ }^{\circ} \mathrm{C}$, current density : 0.5 $\mathrm{A} / \mathrm{cm}^{2}$, Pt loading of anode : $0.28 \mathrm{mg} / \mathrm{cm}^{2}$.

囲となった。 $2 \% ， 3 \% ， 4 \%$ 空気量を増加しても $1 \%$ の 空気添加と同等の性能となった。 前項のエアーブリーディン グなしの条件では, 白金：ルテニウム $=1 ： 2$ において最大 の耐一酸化炭素被毒特性を示したが，エアーブリーディング 運転下では少量のルテニウムが耐一酸化炭素被毒特性に大き な影響を与えた。

Fig. 15 に白金とルテニウムの組成比が，空気添加量 $1 \%$ と $3 \%$ の時の一酸化炭素被毒による電圧低下に与える影響を 示す．空気添加が $1 \%$ の時は，白金：ルテニウム $=2 ： 1$ よ りもルテニウム含有量が低くなるに従って電圧低下が大きく なった．しかしながら，白金：ルテニウム $=6 ： 1$ でも電圧 低下は $30 \mathrm{mV}$ であり， $50{ }^{\circ} \mathrm{C}$ での発電を考慮すると十分に小 さい值となった。一方, 空気添加量が $3 \%$ 時は, 白金：ル テニウム $=1 ： 1.5 \sim 6 ： 1$ の範囲で電圧低下がほぼ一定と なり，その值は約 $15 \mathrm{mV}$ だった. 白金：ルテニウム $=9$ ： 1 では電圧低下は $22 \mathrm{mV}$ だった。今回の一連の結果から, 発電条件にもよるが，エアーブリーディング運転をすれば, 耐一酸化炭素被毒対策に用いるルテニウム量を大幅に削減で きる見达みがあることがわかった。

エアーブリーディングが触媒安定性に与える影響や膜劣化 に及ぼす影響については議論を残すが，近年，ルテニウム溶 出によるカソード特性の低下などが報告されるようになって おり，その対策として，アノード触媒中のルテニウム量削減 の可能性が示されたことは興味深い。また，前項で示したよ うに, 今回の触媒調製法では, 最大の耐一酸化炭素被毒特性 を示すためには白金：ルテニウム＝1：2 が必要だった。こ の場合の優れた一酸化炭素被毒特性の発現は, 白金を被覆し た一酸化炭素が，ルテニウムに吸着した酸素含有成分によっ て酸化除去されることによる性能発現だと推測した。一方, エアーブリーディングの場合には，供給した空気が直接白金 表面に吸着した一酸化炭素を酸化除去するため, 必ずしもル テニウムを必要としない可能性があった. しかし, 今回の実 験において，ルテニウムの添加効果が顕著に確認されたこと から，エアーブリーディングなしの場合と同様，ルテニウム 
が白金へ吸着した一酸化炭素を酸化除去させるのにも貢献し ていることがわかった。

\section{5 ハーフセルにおける触媒の安定性の調査}

Fig. 16 に白金：ルテニウム $=1 ： 1.5$ の触媒を用いた場合 の, 電位保持試験前後の $200 \mathrm{~mA} / \mathrm{cm}^{2}$ における一酸化炭素 $100 \mathrm{ppm}$ 存在下での水素の酸化活性過電圧（耐一酸化炭素 被毒特性）の変化を示した。グラフの縦軸は，[「電位保持後 の一酸化炭素存在下での水素酸化過電圧」-「初期の一酸化 炭素存在下での水素酸化過電圧」〕で示しており，数值の増 加は耐一酸化炭素被毒特性の劣化を示し, 数值の低下はその 性能改善を示している。なお，純水素での水素酸化過電圧は 電位保持試験前後で変化が見られなかった。 $300 \mathrm{mV} ， 600$ $\mathrm{mV}, 900 \mathrm{mV}$ (vs. RHE) の電位保持後では, 耐一酸化炭素 被毒特性の低下は確認されず， $1000 \mathrm{mV}$ (vs. RHE) の電位 保持後では， $10 \mathrm{mV}$ の耐一酸化炭素被毒特性の低下が確認さ

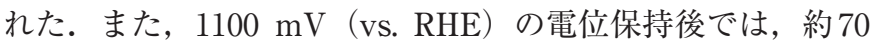

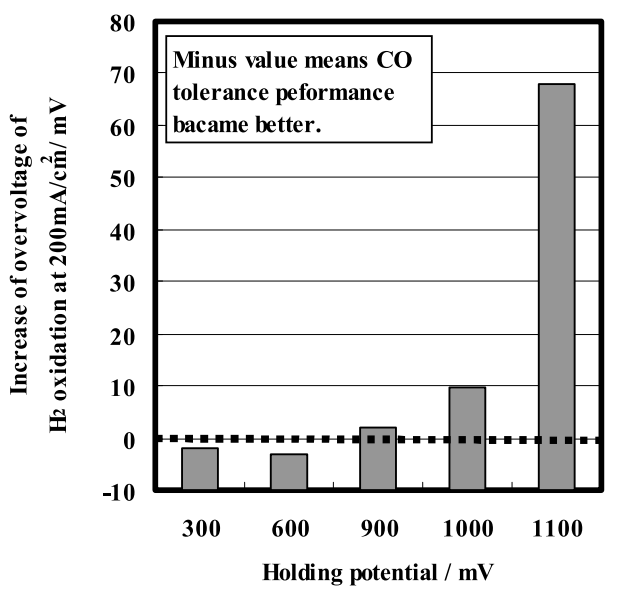

Fig. 16 Increase in overvoltage of $\mathrm{H}_{2}$ oxidation with mixed fuel of $\mathrm{H}_{2}+100$ ppmCO after potential holding at 300, 600, 900,1000 , and $1100 \mathrm{mV}$ for 18 hours in the case of platinumruthenium catalyst of $\mathrm{Pt}: \mathrm{Ru}=1: 1.5$. Cell temperature : $60{ }^{\circ} \mathrm{C}$, current density : $0.2 \mathrm{~A} / \mathrm{cm}^{2}$, Pt loading of anode : $0.56 \mathrm{mg} / \mathrm{cm}^{2}$.

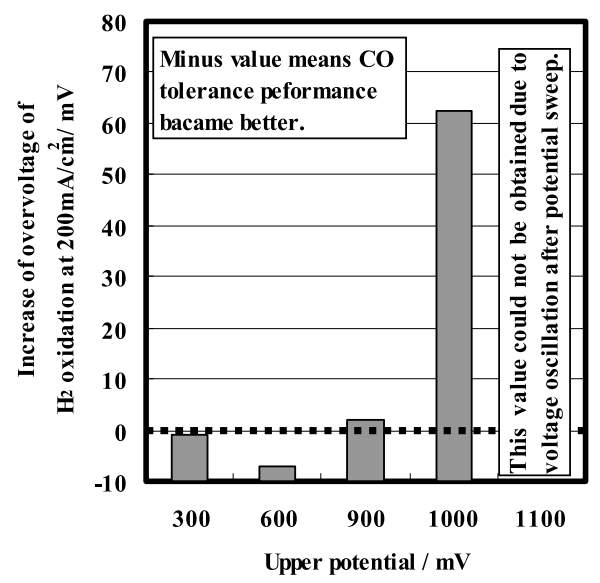

Fig. 17 Increase in overvoltage of $\mathrm{H}_{2}$ oxidation with mixed fuel of $\mathrm{H}_{2}+100$ ppmCO after potential sweep between 10 $\mathrm{mV}$ to $300,600,900,1000$, and $1100 \mathrm{mV}$ for 18 hours in the case of platinum-ruthenium catalyst of $\mathrm{Pt}: \mathrm{Ru}=1: 1.5$. Cell temperature : $60{ }^{\circ} \mathrm{C}$, current density : $0.2 \mathrm{~A} / \mathrm{cm}^{2}, \mathrm{Pt}$ loading of anode : $0.56 \mathrm{mg} / \mathrm{cm}^{2}$.
$\mathrm{mV}$ の耐一酸化炭素被毒特性の低下が確認された。

Fig. 17 に同様にして, 電位掃引試験前後の耐一酸化炭素 被毒特性の変化を示した。なお，純水素での水素酸化過電圧 はこの場合でも変化が見られなかった。上限電位が $300 \mathrm{mV}$, $600 \mathrm{mV}, 900 \mathrm{mV}$ (vs. RHE) の電位掃引後には, 耐一酸化 炭素被毒特性の性能低下は確認されず，10〜1000 mV（vs. RHE）の電位掃引後には, $60 \mathrm{mV}$ の耐一酸化炭素被毒特性 の低下が確認された。また，10～1100 mV（vs. RHE）の電 位掃引後には, 電位掃引後の一酸化炭素存在下での測定では, 一酸化炭素の吸脱着による電位の変動によって測定值が安定 せず，デー夕を取得することができなかった。電位保持試験 と電位掃引試験の比較から, 保持電位または上限電位が $1000 \mathrm{mV}$ と $1100 \mathrm{mV}$ (vs. RHE) の時において, 電位掃引試 験の場合に顕著な性能劣化が確認されたことから，電位掃引 試験の方が，耐一酸化炭素被毒特性に大きな影響を与えてい ることがわかった，家庭用の燃料電池を想定した場合に，停 止時に扔いてアノード電位が空気導入によって $1000 \mathrm{mV}$ （vs. RHE）程度まで上昇することが想定されるが，その範 囲の電位変動において性能低下が確認されたことは興味深く, 今後の実際の燃料電池セルとの相関調查が期待される. とこ ろで, $1100 \mathrm{mV}$ (vs. RHE) 保持後, および，10 mVから $1100 \mathrm{mV}$ (vs. RHE) 幅での電位掃引後の触媒の X 線回折測 定からは, 白金とルテニウムの状態変化を示す物性変化を確 認できなかった。また，透過電子顕微鏡による観察からも， 触媒の粒子サイズの顕著な変化は確認できなかった。したが って, 触媒の耐一酸化炭素被毒特性の低下の理由を物性デー 夕を基に論じることができないが，電位掃引試験などによっ て触媒表面に変化が生じていると推測している。

Fig. 18 に $1000 \mathrm{mV}$ (vs. RHE) の電位保持試験前後， 10 $\sim 1000 \mathrm{mV}$ (vs. RHE) の電位掃引試験前後の耐一酸化炭素 被毒特性の変化に白金ルテニウム組成が与える影響を示す. 白金ルテニウム組成は，電位保持試験前後の特性変化にほと んど影響を与えなかった。一方, 電位掃引試験前後の耐一酸 化炭素被毒特性は, 白金：ルテニウム $=1 ： 1$ の場合に白
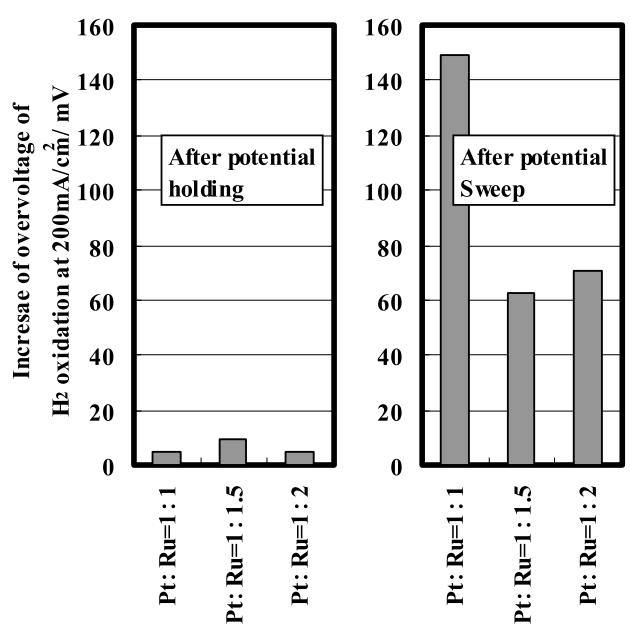

Fig. 18 Increase in overvoltage of $\mathrm{H}_{2}$ oxidation with mixed fuel of $\mathrm{H}_{2}+100$ ppmCO after potential holding at $1000 \mathrm{mV}$ or after potential sweep between $10 \mathrm{mV}$ and $1000 \mathrm{mV}$ for 18 hours in the case of platinum-ruthenium catalyst of from $\mathrm{Pt}: \mathrm{Ru}=1: 1.0$ to $1: 2.0$. Cell temperature $: 60^{\circ} \mathrm{C}$, current density : $0.2 \mathrm{~A} / \mathrm{cm}^{2}$, Pt loading of anode : $0.56 \mathrm{mg} / \mathrm{cm}^{2}$. 
金：ルテニウム $=1 ： 1.5,1 ： 2$ よりも顕著な性能低下が 確認された。 Yamadaらは，硫酸溶液中において，白金ルテ ニウムの組成をパラメーターにして電位掃引試験を実施し, 水素の吸脱着波，一酸化炭素脱離ピーク，銅のストリッピン グボルタモグラムによって表面構造の変化を追跡した。その 結果 ${ }^{35)}$ ，電位掃引時の上限電位が $200 \mathrm{mV}$ （vs. RHE）の時 には, 白金：ルテニウム $=1 ： 1$ の触媒が白金：ルテニウ ム = 1：20触媒に比べて安定であり。一方，電位掃引時の 上限電位が $600 \mathrm{mV}$ (vs. RHE) の時には, 白金：ルテニウ 厶の = 1 ：2 の触媒がより安定な挙動を示すことを示した。 今回の実験の上限電位は $1000 \mathrm{mV}$ (vs. RHE) であったこと から，Yamadaらによる実験における上限電位が $600 \mathrm{mV}$ （vs. RHE）の時の結果と比較すべきであるが，白金：ルテニ ウム $=1 ： 1$ の触媒の劣化速度が大きかった傾向は一致した.

\section{4 結 論}

白金触媒とルテニウム溶液を混合し，ルテニウムを白金近 傍に化学的に還元し, その後加熱処理を施して白金とルテニ ウムを合金化して得られる白金ルテニウム合金触媒について, その白金とルテニウムの組成を変化させた触媒を調製し，触 媒の物性および耐一酸化炭素被毒特性に与える影響について 調查した。この手法で得られた白金ルテニウム触媒は粒子径 が $4 \mathrm{~nm} \sim 8 \mathrm{~nm}$ 程度と比較的大きな触媒粒子径を示した。 また，白金とルテニウムは合金化しており，その結晶構造が 組成比に依存した。白金：ルテニウム $=1 ： 1.5$ よりもルテ ニウムの含有率が低い場合は面心立方格子のみで，白金：ル テニウム $=1 ： 2$ ，および， $1 ： 2.5$ においては面心立方格 子と六方最密格子の 2 相となった. また白金：ルテニウム = $1 ： 3$ においては六方最密格子となった。この手法で得られ た触媒は白金とルテニウムの組成比が白金：ルテニウム $=$ 1：2 以上のルテニウム含有率で特に高い耐一酸化炭素被毒 特性を示した。

また，エアーブリーディング環境下では幅広い組成領域で 十分な耐一酸化炭素被毒特性を示したが，エアーブリーディ ングなしの環境下同様，ルテニウム含有率が高くなるに従っ て耐一酸化炭素被毒特性が向上した。なお，白金：ルテニウ ム $=2 ： 1$ よりルテニウム含有率を高くしても性能向上は確 認できなかった。また，電位保持試験・電位掃引試験による， 白金とルテニウムの組成比が白金：ルテニウム $=1 ： 1$ 1：2の範囲での触媒の安定性比較は，電位保持試験後では 白金とルテニウムの組成比の影響を示さなかったが，電位掃 引試験後では白金：ルテニウム $=1 ： 1$ の組成の時により大 きな性能劣化を示した.

1) US Patent, 1077128 (1964)

\section{文 献}

2) L. W. Niedrach, D. W. Mckee, J. Paynter, and I. F. Danzig, J. Electrochem. Tech., 5, 318 (1967).

3) D. W. Mckee and A. J. Scarpellino, J. Electochem. Tech., 6, 101 (1968).

4) M. Watanabe and S. Motoo, J. Electroanal. Chem., 60, 275 (1975).

5) P. N. Ross, K. Kinoshita, A. J. Scarpellino, and P. Stonehart, J. Electroanal. Chem., 63, 97 (1975).

6) H. -F. Oetjen, V. M. Schmidt, U. Stimming, and F. Trila,
J. Elecctochem. Soc., 143, 3838 (1996).

7) M. Iwase and S. Kawatsu, Proceedings of $13^{\text {th }}$ International Electric Vehicle Symposium, Vol.1 p.675 (1996).

8) European Patent, 0838872 A2 (1998).

9) Y. Morimoto and E. B. Yeager, J. Electroanal. Chem., 441, 77 (1998).

10) T. Ioroi, Z. Shiroma, S. Yamazaki, N. Fujiwara, H. Senoh, and K. Yasuda, Proceedings of The $\mathbf{4 6}^{\text {th }}$ Battery Symposium in Japan, p.124 (2005) [in Japanese].

11) S. J. Cooper, A. G. Gunner, G. Hoogers, and D. Thompsett, Proceedings of $2^{\text {nd }}$ International Symposium on "New Materials for Fuel Cell and Modern Battery System", p.286 (1997).

12) H. A. Gasteiger, N. M. Markovic, P. N. Ross. Jr., and Elton J. Cairns, J. Phys. Chem., 98, 617 (1994).

13) H. A. Gasteiger, N. M. Markovic, and P. N. Ross. Jr., J. Phys. Chem., 99, 8290 (1995).

14) H. A. Gasteiger, N. M. Markovic, and P. N. Ross. Jr., J. Phys. Chem., 99, 16757 (1995).

15) K. A. Friedrich, K. -P. Geyzers, U. Linke, U. Stimming, and J. Stumper, J. Electroanal. Chem., 402, 123 (1996).

16) T. Springer, T. Zawadzinski, and S. Gottesfeld, Proc. Electrochem. Soc., 97, 15 (1997).

17) F. Bautie de Mongeot, M. Scherer, B. Gleich, E. Kopatzki, and R. J. Bhem, Surf. Sci., 411, 249 (1998).

18) W. F. Lin, M. S. Zei, M. Eiswirth, G. Ertl, T. Iwashita, and W. Vielstich, J. Phys. Chem. B, 103, 6968 (1999).

19) L. Giorgi, A. Pozio, C. Bracchini, R. Giorgi, and S. Turtu, J. Appl. Electrochem., 31, 325 (2001).

20) A. E. Russell, S. Maniguet, R. J. Mathew, J. Yao, M. A. Roberts, D. Thompsett, J. Power Sources, 96, 226 (2001).

21) M. Iwase and S. Kawatsu, Proc. Electrochem. Soc., 95, 12 (1995).

22) S. Gottesfeld and J. Pafford, J. Electrochem. Soc., 135, 2651 (1988).

23) US Patent, 4910099 (1990).

24) T. A. Zawodzinski, C. Karuppaiah, F. Uribe, and S. Gottesfeld, Proc. Electrochem. Soc., 97 (1997) 139.

25) J. Schmidt, M. Noeske, H. A. Gasteiger, R. J. Behm, P. Britz, and H. Boennemann, J. Electrochem. Soc., 145, 925 (1998).

26) H. Boennemann, R. Brinkmann, P. Britz, U. Endruschat, R. Moertel, U. A. Paulus, G. J. Feldmeyer, T. J. Schmidt, H. A. Gasteiger, and R. J. Behm, J. New Mat. Electrochem. Syst., 3, 199 (2000).

27) M. Watanabe, M. Uchida, and S. Motoo, J. Electroanal. Chem., 229, 395 (1987).

28) K. A. Starz, E. Auer, Th. Lehmann, and R. Zuber, Proceedings of the $3^{\text {rd }}$ International Fuel Cell Conference, p.93 (1999).

29) H. Daimon and Y. Kurobe, Catalyst Today, 111, 182 (2006).

30) US Patent, 6066410 (2000).

31) US Patent, 6007934 (1999).

32) US Patent, 6339038 B1 (2002).

33) Japanese Patent, 3839961 B2B2 (2006).

34) M. S. Wilson and S. Gottesfeld, J.Electrochem. Soc., 139, L28 (1992).

35) H. Yamada, D. Shimoda, K. Matsuzawa, A. Tasaka, and M. Inaba, ECS Transactions, 11, 325 (2007). 